\begin{tabular}{|c|c|c|}
\hline $\begin{array}{l}\text { EXCELLENT } \\
\text { PUBLISHERS }\end{array}$ & $\begin{array}{c}\text { International Journal of Current Research } \\
\text { and Academic Review } \\
\text { ISSN: 2347-3215 (Online) }:, ; \text { Volume } 5 \\
\text { Journal homepage: http://www.ijcrar.com }\end{array}$ & \\
\hline
\end{tabular}

doi: https://doi.org/10.20546/ijcrar.2017.509.010

\title{
Morbidity Profile of Geriatric Population in Junnar Taluka of Pune District of Maharashtra, India
}

\author{
Neha Ande ${ }^{1 *}$ and Rahul Bogam ${ }^{2}$ \\ ${ }^{\text {I} B h a r a t i ~ V i d y a p e e t h ~ U n i v e r s i t y ~ M e d i c a l ~ C o l l e g e, ~ P u n e, ~ M a h a r a s h t r a, ~ I n d i a ~}$ \\ ${ }^{2}$ Ministry of Higher Education, Kingdom of Saudi Arabia \\ *Corresponding author
}

\begin{abstract}
Ageing presents both challenges and opportunities. It is reported that approximately $50 \%$ of geriatric population in India is suffering from chronic diseases. It poses huge responsibility on health care services mainly in developing countries like India. The present study was conducted to determine various morbidity patterns among elderly population in Junnar Taluka of Pune District. A Cross- Sectional study was conducted at one of the randomly selected villages of Junnar Taluka of Pune District, Maharashtra. On occasion of 'General Health Camp' conducted at same village, 86 patients above 60 years of age who attended health camp were included as study participants. The sociodemographic as well as clinical information was collected by using pre-validated structured proforma and the data was analysed. The study reported various morbidity patterns of diseases among study participants. There were maximum 'Locomotor' problems (71.42\%) followed by 'Auditory' problems $(61.90 \%)$. It reiterates the need for screening of elderly population for different diseases for which they are prone.
\end{abstract}

\section{Article Info}

Accepted: 30 August 2017

Available Online: 20 September 2017

\section{Keywords}

Geriatric,

Morbidity,

Old,

Pune

\section{Introduction}

Aging is generalized and progressive loss of body functions resulting in various forms of morbidities as well as mortalities. (K.Park, 2015). Ageing presents both challenges and opportunities. It will increase demand for primary health care and long-term care, require a larger and better trained workforce and intensify the need for environments to be made more age-friendly (WHO report, 2015).

Common conditions in older age include hearing loss, cataracts and refractive errors, back and neck pain and osteoarthritis, chronic obstructive pulmonary disease, diabetes, depression, and dementia. Furthermore, as people age, they are more likely to experience several conditions at the same time (WHO report, 2015).

It is reported that approximately 50\% of geriatric population in India is suffering from chronic diseases.

It poses huge responsibility on health care services mainly in developing countries like India (Kumar V, 1997).

The present study was conducted to determine various morbidity patterns among elderly population in Junnar Taluka of Pune District. 


\section{Materials and Methods}

A Cross- Sectional study was conducted at one of the randomly selected villages of Junnar Taluka of Pune District, Maharashtra. On occasion of 'General Health Camp' conducted at same village, 86 patients above 60 years of age who attended health camp were included as study participants. Informed Consent was obtained from participants. The sociodemographic as well as clinical information was collected by using pre-validated structured proforma. Physical examination was performed by experienced doctors. Blood pressure was measured by standard Sphygmomanometer. Entire data was entered into Microsoft Office Excel Sheet and was analysed.

\section{Results and Discussion}

In present study, out of 84 study participants, 47 $(55.95 \%)$ were males and $37(44.04 \%)$ were females. All participants were in age range of 60 to 85 years.
Only $6(7.14 \%)$ participants belonged to 'Nuclear family' and remaining $78(92.85 \%)$ were from 'Joint Family'. This finding corroborates with study finding of Rajashree Bhatt et al., (2011) where $92.7 \%$ of old population were living in joint family. Srivastava and Mishra also reported maximum number of geriatric population belonging to joint family. (Srivastava \& Mishra, 2005). Thirty six (42.85\%) participants were illiterate and rest $48(57.14 \%)$ were educated up to primary level.

Table 1 indicates various morbidity patterns of diseases among study participants. There were maximum 'Locomotor' problems (71.42\%) followed by 'Auditory' problems (61.90\%). Males were having more locomotor problems than females. This finding was comparable with study conducted at Urban area of Udaipur, Rajasthan where locomotor problems were high in females (Rahul P.et al., 2004). Rajashree Bhatt et al., (2011) also reported high number of locomotor problems in females (50\%) as compared to males (45.09\%).

Table.1 Morbidity Profile of Study Participants $(n=84)$

\begin{tabular}{|l|l|l|l|}
\hline \multicolumn{1}{|c|}{ Morbidity } & \multicolumn{1}{c|}{ Male (\%) } & \multicolumn{1}{c|}{ Female (\%) } & \multicolumn{1}{c|}{ Total (\%) } \\
\hline Diabetes Mellitus & $6(12.76 \%)$ & $9(24.32 \%)$ & $15(17.85 \%)$ \\
\hline Hypertension & $19(40.42 \%)$ & $12(32.43 \%)$ & $31(36.90 \%)$ \\
\hline Locomotors & $37(78.72 \%)$ & $23(62.16)$ & $60(71.42 \%)$ \\
\hline Psychological & $30(63.82 \%)$ & $11(29.72 \%)$ & $41(48.80 \%)$ \\
\hline Respiratory & $12(25.53 \%)$ & $08(21.62 \%)$ & $20(23.80 \%)$ \\
\hline Skin & $09(19.14 \%)$ & $10(27.02 \%)$ & $19(22.61 \%)$ \\
\hline Auditory & $29(61.70 \%)$ & $23(62.16)$ & $52(61.90 \%)$ \\
\hline Vision & $21(44.68 \%)$ & $13(35.13 \%)$ & $34(40.47 \%)$ \\
\hline Others & $05(10.63 \%)$ & $07(18.91 \%)$ & $12(14.28 \%)$ \\
\hline
\end{tabular}

In present study, 19 (40.42\%) males and 12(32.43\%) females had hypertension problem. HM Swami et al., (2002) in his study reported $53.59 \%$ of males and $61.24 \%$ of females were having hypertension. The percentage of hypertensive males and females was $25.7 \%$ and $38.09 \%$ respectively in study conducted at Ahmadabad, Gujarat (Rajashree Bhatt et al., 2011)

Twelve (14.28\%) participants were suffering from other health problems like Diarrhoea, generalized weakness, Upper respiratory tract infections (URTIs),Oedema, pallor etc. Seventy eight $(92.85 \%)$ participants were indulged into different forms of tobacco addiction like smoking, tobacco chewing, pan masala, khaini etc.

The present study reported various forms of disease morbidities among geriatric population with high percentage of 'Locomotor' problems followed by 'Auditory' problems. It reiterates the need for screening of elderly population for different diseases for which they are prone. This can be done through periodic geriatric health camps / general health camps. They should be educated in simplified manner about these health problems.

\section{Acknowledgements}

We are thankful to Dr.Ismail and Dr.Karuna for their valuable help in implementation of this study.

\section{References}

Kumar, V., 1997. Aging in India. Indian J Med Res.; 106:257-64. 
Park, K., 2015. Textbook of Preventive and Social Medicine. $22^{\text {nd }}$ ed. Banarsidas Bhanot Publishers, Jabalpur, India.

Rahul, P., Chaudary S K, Singh V S 2004. A Study of Morbidity Pattern among Geriatric Population in anUrban area of Udiapur Rajasthan $I J C M, 29$ (1):35-40.

Rajshree Bhatt, Minal S Gadhvi1, K N Sonaliya, AnandSolanki, HimanshuNayak 2011. An Epidemiological Study of the Morbidity Pattern among the Elderly Population in Ahmedabad, Gujarat. National Journal of Community Medicine, 2 (2): 233-36.

How to cite this article:

Neha Ande and Rahul Bogam. 2017. Morbidity Profile of Geriatric Population in Junnar Taluka of Pune District of

Maharashtra, India. Int.J.Curr.Res.Aca.Rev. 5(9), 66-68. doi: https://doi.org/10.20546/ijcrar.2017.509.010
Srivastava, H.C., Mishra N R 2005. Living arrangement \&morbidity pattern among elderly in rural India. International Institute for population science Mumbai: 1-7.

Swami, H.M., VikasBhatia, RekhaDutta, SPS Bhatia 2002. A Community Based Study of the Morbidity Profile among the Elderly in Chandigarh. Bahrain Medical Bulletin, 24 (1):1-4.

World Health Organization (WHO) report 2015. Ageing and Health. Available from http://www.who.int/mediacentre/factsheets/fs404/en / (Accessed on $24^{\text {th }}$ July 2017). 